\title{
Scarcity, Exit, Voice and Violence: The State Seen through eGovernment
}

\author{
Rahul De' and J.B. Singh \\ Indian Institute of Management Bangalore \\ \{rahul, jangb06\}@iimb.ernet.in
}

\begin{abstract}
This paper examines if, and how, the manner in which the state is viewed changes when an e-government system is implemented. The motivation for this paper lies in the fact that the nature of the state is under-theorised in e-government literature. The state, in a developing country context, is formulated as being scarce, presenting choices of exit and voice to citizens, and of having authority over violence. A specific grievance registration system from India, called Lokvani, is used as an example to show the effect of the system on how residents of that region view the state. Field data collected from participant interviews of those interacting with the system is analysed. The results show that the nature of the state changes when the system is used, however, for some aspects it remains the same. Further, the paper concludes that it is imperative to have a formal theory of the state for evaluating and designing egovernment systems.
\end{abstract}

Keywords: e-government, state, scarcity, exit, voice, violence, India.

\section{Introduction}

In order to understand the role that e-government is expected to perform, it is necessary to assume the role of the state. E-government, after all, is a "technology" of the state; the state is deploying such a technology to address certain concerns it has about its own functioning or about the effects it expects to see from its functioning. The state remains an entity that is assumed to have an over-arching, ideology-like presence in the examination of e-government, more in the background as assumptions and a priori notions, and less as an explicit object of study.

The state is under-theorised in e-government literature. When the role of the government, the bureaucracy, the administration, elected representatives, and public bodies are examined, the state is a referent and an implicit construct. This hides the complexity of the nature of the state, its manifestations, and the manner in which its role is assumed in e-government design, implementation and evaluation. When the state is explicitly examined, as is the case in a few papers, the focus is more on the functions and the mechanisms of the state, through its administrative and governance capacities, rather than on its intentions, role, ideology and how it is perceived. 
This paper examines the nature of the modern nation state, in the context of e-government deployments in developing countries. The state manifests itself in a manner that is 'seen' by the population in different ways. In this situation, the technologies used by the state, such as e-government, too are seen in different ways by different population groups. It is important to understand the manner in which the state is manifested to fully understand the role and impact of technologies such as e-government. In the absence of a theory of the state, egovernment research is bereft of an ontological basis.

\section{Background Theory and Research Questions}

\subsection{The State}

The state is theorised in myriad ways in the political science, sociology and anthropology literature. It is often used with the term 'nation' as the nation state or as the nation-state. Theorists contend that the state embodies the notions of territoriality and sovereignty [13, where a specific geographical region binds the territory of the state within an administrative structure that has power and authority. The nation has a cultural connotation, as a formation to which citizens identify and from whom the authority of the state is legitimised.

The ideas of both the state and the nation have endured considerable modification with the advent of the globalised, connected world [1213. The state's territorial control is challenged by free flows of money, information, and in some cases, labour, across boundaries. The state's sovereignty is challenged by multilateral bodies such as the World Bank and the United Nations that impose authority over the state and its mechanisms. Such issues crop up most prominently when the territorial boundaries are challenged by protectionism or insularity, to prevent free trade of goods or free flow of labour. Those states that would once have championed free flows are bound to demand restrictions, owing to their own vulnerability to global forces.

The idea and the discourse around the nation too is contested in the modern globalised age. A national identity is often questioned on the grounds of regional differences and ethnic identities, a national agenda is often regarded as co-opted by the elite, and the idea of being a national is challenged, and reinforced, by trans-national migrations and loyalties.

The state is the provider of the mechanisms of rule - all the institutions that perform governance, ensure security, and regulate the markets ([13]; page 10). It is embodied in the institutions of governance, such as the bureaucracy, elected representatives, the judiciary, the constitution and the system of laws and policies. When contrasted against the market - as is often the case in popular writing - the state is all that which has authority outside of the market and civil society.

It is important to recognise that the state is an abstract idea that has different meanings in different contexts and to different people. People often 'see' it in different ways 4. Further, it is enmeshed in the everyday lives and practices of ordinary people. "The sphere of everyday practices is the primary arena in which people learn something about the state. Whether it is the practice of 
standing in line to obtain monthly rations or to mail a letter, getting a statement notarized or answering the questions of an official surveyor, paying taxes or getting audited, applying for a passport or attending a court hearing, the state as an institution is substantiated in people's lives through the apparently banal practices of bureaucracies." ([13]; p11).

The state is seen to have a particular form and character, and ways in which it is visible, experienced and rendered in the popular imagination. It is both an objective real, external and powerful to the lives of people, and realised through subjective experience. Scholars argue that the legitimacy of the modern state is bound in popular sovereignty [3], or in the will of the people.

When the state is "encountered" or experienced in the everyday practices of ordinary people, it impresses its presence upon those who experience it. This impression varies by the nature of the encounter - for some it may mean a loss of money or dignity, while for others it may entail a satisfying experience. The memory of this experience shapes the way the state is seen. Corbridge et. al. (2005) have created a typology of experiences that ordinary citizens, particularly poor and marginal citizens, have of the state. We present below a brief review of this typology.

One reason why the poor and marginal have to meet with the state is to avail of entitlements and subsidies. These may form incentive transfers under specific schemes, or as direct assistance for disabilities or relief. Representatives of the state, bureaucrats and functionaries at the lowest levels of the state machinery, are the ones who have to be seen for this purpose. These encounters entail transfers of monies, from the state to the citizen, and also, in many cases, from citizens to the state. Citizens see the state as both providing incentives and money, and also as demanding and extracting monies through bribes. These experiences vary across situations and contexts.

Experiencing the state is also quite varied when it comes to transfer of information. In India, the poor experience the state through the census, the regular surveys that are carried out by various agencies, and, recently, through IT-enabled means (iris-scans and finger-printing). The state demands and obtains information, either through the voluntary effort of filling out surveys or through the need to fill out forms for incentive payments. The state also informs citizens, usually through newspaper reports, posters in villages, and through radio and television. Citizens experience the information from the state directly, through viewing or hearing, or indirectly, by hearing experiences of others.

The state is experienced in everyday practices and as such is shaped as an entity with some characteristics in the view of citizens. There are many characteristics or properties, but in the situation of marginal populations viewing the state in a developing country like India, a few properties stand out. These are discussed below.

\subsection{Properties of the State}

Scarcity. For marginal populations the state is never abundantly available. Its most important property is scarcity. Even though the presence of the state, in 
terms of officials and functionaries, is evident in a broad geographical spread across India, the availability of such functionaries is invariably scarce. Citizens have to travel long distances, in many cases, to avail of the state's facilities, have to wait in long queues, have to deal with someone who is not of the same caste or community, may speak a different language, and may require engaging with a number of intermediaries.

The 'grand designs' of the state, crafted in national capitals and in the thinktanks and centres of policy planning, is far removed from the everyday experiences of ordinary citizens, and when they are to be realised 'on the ground' face challenges of resistance, denial and distortion. The state becomes scarce here owing to the disjunction between the design of the policy prescriptions and the reality of the specific region.

The scarcity of the state is also a function of the emerging political economy (4]; page 34 ). With large middle castes and community groups emerging as powerful political blocks, in most parts of India, who have access to the resources of the state, marginal communities are excluded.

Exit and Voice. In a seminal book, Hirschman 8] explored the ideas of Exit and Voice that customers, citizens, employees have with regard to the organisation or the state. The idea of exit is that of withdrawal from participation or engagement. When customers are not satisfied with offerings available at a commercial establishment they may exit and go to a rival. Similarly, citizens who are demanding a service from the state may want to exit if the service is not provided, by not demanding at all or moving to another state. Exit represents a physical or mental withdrawal from participation, having once considered the option.

Exit is often enabled by or inhibited by various conditions, of the organisation or the state in which the individual is in, or by the material conditions of the individual. Immovable property, for instance, prevents citizens from exiting the state, or, for citizens of countries with dictatorships there may be stiff penalties for emigrating. The possibility of exit drives behaviour of individuals - those who can may exercise a choice of staying on to see if conditions improve, whereas those who cannot have to modify their behaviour to suit the existing conditions.

Voice is the ability to provide feedback or protest the conditions of the organisation or state in which the individual currently resides. Voice is conditioned by the situation of the agent, and is prompted by the treatment the agent receives. Positive feedback to the organisation by the agent reassures the organisation that it has served well, however, voice is more important when the feedback is negative. In the latter case the organisation or the state receives a signal to amend or repair its service. In the modern era, voice can and does assume many forms - email messages, phone calls, letter campaigns, street protests, class action lawsuits, and so on.

Voice too is amplified or damped by various conditions. In situations where the agents can exit, voice simply does not arise. In situations where there are severe penalties for raising a voice, such as in a dictatorial state or within some organisations, where exit is not possible then voice is usually muted or silent. 
Hirschman argues that the combinations of possibilities of exit and voice can lead to nuanced arrangements of individuals and organisations. For example, when the state is providing a substandard service, such as a healthcare facility without any supplies, and if the residents in the nearby area have an option to exit, there will be none who will raise a voice, and enable the state to continue with the same sorry state of affairs. This happens frequently in India for schooling, healthcare, city transportation - where the alternatives provided by the private sector allows citizens to exit and not raise their voice. "Once this avoidance mechanism for dealing with disputes or venting dissatisfaction is readily available, the contribution of voice - that is of the political process - to such matters is likely to be and to remain limited." 9].

Violence. Max Weber's classic definition of the state is that of an entity that has the sole authority over violence in a given territory. The state exercises this authority over violence through the police and the army. Although other organisations may have a right to use violence, through a private army for instance, this is only possible within the authority of the state.

Marginal citizens of developing countries often see only this view of the state, as a violent enforcer. The police are often viewed as agents of those who have access to state power, with their violence unleashed only on those without access.

\subsection{Existing E-Gov Literature}

The existing literature in e-government theory implicitly assumes the role and function of the state. In the normative view the state is assumed to want to improve the efficiency and effectiveness of the administration by providing services through electronic means. This view is effectively shared by many research papers, those commenting on the basis for e-government development and its trajectory, as well as those that critique the current status of research [1017,17]. The intentions of the state are implicit in the efforts to increase efficiency, help create networks for interconnectivity, improve service delivery, increase interactivity, and help with decentralisation, transparency and accountability [17.

In the descriptive view, where researchers depict the functioning of the state, the intention of the state is not explicated but is revealed by the manner in which the state implements or designs e-government systems. In describing the implementation of a system in Guatemala [15], for example, the authors uncover that the state has 'deep structures' such as organisational arrangements, distribution of power, core beliefs and values, and control systems that determine how the system is eventually received. The functioning of the state evolves as a 'punctuated equilibrium' with brief periods of rapid change between long stretches of very little change.

In another example, the researchers [2] find that the state is moulded by certain 'regimes of truth' and 'the care of the self' that shape the implementation of e-government systems. The state alternately passes through discourses of modernisation and maintaining status quo, as harboured by different regimes. Further, the planning and design of systems is influenced by a rationality that, through critical reflection, assumes certain truths about life experiences. 
In few cases, e-government research has explicitly assumed a form and role of the state [5], where it is assumed to foster centralisation of control and operate through a discourse of de-politicisation. However, there is very little research of this nature. The state remains largely un-theorised in the extant e-government literature. This leads to the central research question of this paper.

\subsection{Research Question and Methodology}

The state is experienced by citizens in particular ways, in that, the viewed state has certain properties. These properties include those of scarcity, exit and voice, and violence. E-government research has implicitly assumed a function and role of the state, but has rarely theorised it formally. The central issue addressed by this paper is how a theory of the state can be formed in light of e-government systems implementations. The main research question is:

How is the state viewed through the lens of an e-government system? More specifically, how are the properties of scarcity, exit and voice, and violence of the state experienced when e-government systems are implemented?

To answer this question, we examine one particular e-government system from India. This system is used primarily as a complaints registration system that enables citizens of a particular district in a relatively poor province in India, that of Uttar Pradesh. The system mainly enables residents of the district to file complaints and grievances online through public kiosks.

The methodology for this study was an ethnographic case study method [18. The data for this particular e-government system was collected as part of a much larger research programme that included several e-government projects across India. This methodology was adopted as the objective was to study the phenomenon of the e-government system in its natural setting where there is little control over the system or the people using the system. Further, the research entailed asking how and why type of questions (rather than what type), and also required probing the respondents through follow-up questions.

One researcher, a co-author of this paper, resided in the district of the project for two months, in early 2010. The researcher lived in a village house, as a guest of one of the residents. Using this as a base he made deep contacts within this village and in surrounding villages. He traveled to the project kiosks located in the district, interacted with the kiosk owners, the users and also those who did not use the kiosks. During the fieldwork, data was collected through unstructured and semi-structured interviews, focus group discussions, document reviews, participant observation and by collecting physical artefacts. The researcher maintained notes on all interviews, and wherever permitted, took photographs of the respondents and the locations. A total of 78 interviews of independent citizens, kiosk owners, government officials, and village council members were conducted. In addition, 2 focus group interviews were conducted, and documents amounting to about 500 pages were obtained to support the analysis.

One particular line of questioning that was maintained throughout was that of seeking the differences in perceptions of the system between dominant and non-dominant caste groups [6]. 


\section{The Lokvani System}

Lokvani was initiated in December 2004 in the Sitapur district of the state of Uttar Pradesh, as an internet-based computer kiosk with a facility for registering online grievances. Being a backward district with only $38 \%$ literacy, Lokvani was envisioned not only to open a channel for redressing citizen's grievances through an online portal but also for a potentially large application of ICTs - such as providing information about various government schemes, issuing land and caste certificates etc. After its launch Lokvani became more popular for its grievance facility because of its ability to directly connect people to the highest authority, the District Magistrate (DM) of the district for their general complaints, without physically visiting the DM's office. The user interface of Lokvani was designed in the local language of Hindi and was hosted on an internet web server so that any person could register a complaint from anywhere, not necessarily from their village centres. The entrepreneurs charged fees as fixed by the government from the citizens, in a public-private partnership model [14]; these were Rs 15 (about \$0.3) per complaint.

After the implementation of Lokvani, an aggrieved citizen could go to the Lokvani centre and lodge a complaint with the help of the kiosk operator. The operator logs in to the Lokvani system with a login and password through a web browser and enters the details of the complaint in a specific format. When the operator submits a complaint, the system generates a complaint number that the operator passes to the complainant so that he can track or check the status of the complaint on the next visit to the centre. All the complaints logged through the system are addressed to the DM irrespective of the concerned department, thus neither the operator nor the citizen have to bother about whom to send the complaint. After the complaint is submitted it is sorted at the DM's office which has a six-member team dedicated to this job. Here complaints are marked to the concerned officer/ department (if it is a police matter then it is marked to the relevant police station officer). Depending on the nature of the complaint a timeframe of resolution is determined by this team. The name of the officer to whom the complaint is marked is noted, and the deadline for the resolution is uploaded on the server. If required, either the concerned officer or field level employees visit the complainant. In a police case, station officers direct the constables to visit the place to enquire about the dispute registered. When the officer responds to the complaints, the response or resolution description is entered back into the system against the complaint number which citizens will have access to, to see the outcome of the resolution.

\section{Data and Analysis}

In this section we present the field data on the Lokvani system and our analysis of it. The two are combined to save space.

Scarcity - the original design of the Lokvani system was to address the issue of scarcity. This is evident from the statements made by the then Chief Minister of the state, in a media interview in 2005: “... the Lokvani project particularly 
will benefit the common man greatly...realisation of the benefits will be most by the villager who wanders to district headquarter and tehsil office for his general grievances... Now there is a facility - Lokvani near the village from where he can avail all the services [Translated from Hindi by authors.]"

Within the current governance mechanism available at the village level in Sitapur, there are three broad approaches exercised by the citizens to voice their grievances and disputes. The first mechanism is that of mediation by local individuals or bodies; when individuals seek help of an influential person or approach the Village council to resolve the dispute. Village councils often deal with complaints by providing suggestions on public administration [16]. However, such councils reinforce the enduring social structures due to the presence of dominant caste or community members in their administrative bodies [11. The second mechanism is local government intervention either through the DM's office or through the relevant government department, including police officials. The third mechanism consists of formal legal institutions, such as the court, to solve grievances and disputes. Dispute resolution touches everyday life in the village society.

Prior to Lokvani, persons of non-dominant castes, minorities and the poor generally relied on the first two mechanisms for dispute resolution. The relatively rich and politically connected persons tended to access the official justice system. If an aggrieved citizen had to seek the intervention of local government for dispute resolution, he had to physically visit either the DM's office at the district headquarters, the sub-district headquarters or the local police station (if it was a police matter). Sometimes, if the complaint was not registered at the local police station, citizens could seek intervention from the DM's office to get it registered. In Sitapur, citizens have a window of two hours a day to interact with the DM for registering their grievances. A heavy work load at the DM's office and a very short time window for citizens resulted in very few grievances being addressed and sometimes citizens traveled multiple times to get their complaints acknowledged. This process actually discouraged individuals to even seek redressal.

The state's scarcity is considerably reduced by the presence of Lokvani. Where earlier there were three manual means of accessing the state, the Lokvani system has enhanced the second method, of going to the DM, through electronic means. This is evident from both the type and volume of complaints registered within the system. Looking at the secondary data on usage of the Lokvani system we find the types of complaints depicted in Table 1. This summary is based on a random sample of complaints at various Lokvani centres.

The total number of complaints in the system was 11,697 in the the year 04-05, which peaked at 45860 the following year, and then gradually declined to about $11 \mathrm{k}$ by 2011 .

Exit - While removing scarcity Lokvani enabled citizens of Sitapur to find an electronic means by which to access the state. This process also allowed them to find ways of exiting other engagements with the state. 
Table 1. Category of Complaints

\begin{tabular}{|l|l|}
\hline Category & Description \\
\hline Farming-Related & $\begin{array}{l}\text { Problem with tenant cultivation; dispute with Batai (tenancy) } \\
\text { agreement; problem with government land use; problems in dealing } \\
\text { with a government office (concerned with farm loan, government } \\
\text { shops of fertilisers or seeds) } \\
\text { Dispute in collecting work pay; dispute in money lending; a problem } \\
\text { with a government official (accusation of bribery) } \\
\text { Housing construction rights (drainage system, yard related); dis- } \\
\text { pute with encroachment of farm land; Medh Bandi (farm boundary } \\
\text { dispute) } \\
\text { Problem with a neighbour, intimidation, harassment } \\
\text { Complaint of personal injury or theft } \\
\text { Dowry related; a consumer dispute; matrimonial problem; a family } \\
\text { dispute (property division) etc. }\end{array}$ \\
\hline Personal Injury \\
Other
\end{tabular}

Ram Ajore of Sitapur (of a non-dominant caste), of Biswan sub-district (Bhauli village), had complained at the DM's office related to an encroachment of land. He had first tried with the police, and not succeeding there, had then tried to register the complaint with the DM about 10 years ago. Then, for a decade, he engaged with the state to seek a resolution, but to no avail. When Lokvani was introduced, he exited his earlier engagement and filed a fresh complaint through the system in 2006. In another case, Munni, a 22 year-old married woman from a non-dominant caste community, was assaulted by a youth of a dominant caste while her husband was away at work. Later, when her husband returned and tried to file a complaint with the police, he was rebuffed. He did not return to the police, as he had been instructed, but filed a complaint through Lokvani.

In the district of Sitapur, the marginal and non-dominant castes would exit the system of filing a complaint owing to the scarcity and the difficulties associated with dealing with the state. Exit meant not filing a complaint, withdrawing a complaint, or reneging from long queues outside the DM's office. Exit would also happen in the case of demands of state-mandated incentives or entitlements, where denial or unavailability of access would force recipients to exit, or give up on their entitlements.

Lokvani has changed the situation with regard to exit. Residents can file a formal complaint, or register a request, as compared to the past, but they are not assured of recompense from the state. There is exit from an earlier form of engagement, however there is no guarantee of redress.

It must be pointed out that engagement with Lokvani too is being exited. The data regarding usage of Lokvani shows that citizens of Sitapur, not being assured of redress through Lokvani, are not using it as much as in the initial stages.

Voice - The field data clearly shows that post Lokvani, citizens were not silent about their grievances and it has given them freedom to voice their problems. 
As a focus group transcript highlights this situation: "...before Lokvani people went to Sitapur only in very serious cases..when Lokvani came more people are talking about their problems."

One respondent, Damyanti, from a non-dominant caste, is currently separated from her husband and living with her sister. She showed a printout of a complaint that she had registered and said: "My husband has kicked me out from the house forcibly...I want the house which my husband is not ready to give. I went to the police but they did not listen to me and said it is a matter between husband and wife. Now I have done Lokvani ..., (hopefully) sarkar (government) will listen to me otherwise God will listen to me." This case was forwarded to the sub-district's block development officer for further investigation.

A critical issue is that citizens, particularly women and the poor, face problems in registering their complaints with the district administration and with the local police. This problem has also has been acknowledged by the Human Rights Watch throughout India. The Human Rights Watch (2009) report states that: "Crime victims frequently face police delays or refusal to investigate their complaints of crime. Victims of violence, particularly violence that is genderbased, frequently fail to report crimes because they fear being physically harmed at the police station or while traveling to it, especially at night. Crime victims who are poor and without legal counsel are especially vulnerable to police intimidation. (2009:p-42)."

Not having enough means or the fear of facing government officials acts as a barrier and the poor, landless labourers and women stand out as a particularly reluctant group, when it comes to registering complaints for seeking redress. Lokvani was conceptualised to give a voice to these groups and also to make the grievance redressal system more efficient. Where the manual system was rife with caste politics, the new system at least allows members of non-dominant castes to register their complaints.

Both the (former) Chief Minister and the project champion assured citizens that they now had a voice they did not have before. This voice was enabled through Lokvani. The implication of having a voice, in theory, means that the organisation or state that listens to this voice adjusts its own functioning to respond to the needs of its clients. Although, Lokvani did enable voice in terms of initiating the first part of the process of registering the complaint, there is little evidence to suggest that the state significantly changed its functioning or its efficiency. The problems were localised to a large extent, without having any impact on state policy, procedures, new laws, or re-arrangements of administration. The project champion almost admitted this in an interview.

Violence - In Sitapur district, violence is legally sanctioned to the police. This aspect of the state remains the same even with the presence of Lokvani. Local caste politics and dominance remains a determinant of how state power will be aligned.

Shyama is a widow who lives with her small daughter. She used to pile cow dung cakes in front of her house, which also faces the front yard of her neighbour. Her neighbour, belonging to a dominant caste, objected to the cake piles as it was 
damaging their aesthetic view of the yard. They also threatened her of physical violence if she ever did it again. This is what Shyama had to say: "When I first went to the police station they did not register my complaint...even yelled at me saying that it is a minor neighbour dispute...but after Lokvani, police came to my house for an inquiry." Though Shyama was not allowed to pile the dung cakes in front of her house after the resolution meeting, she pointed to the fact that Lokvani forced police officials to visit her house. Shyama's case clearly shows that violence is condoned for those within dominant groups, but for her the promise of violence ensured she changed her behaviour.

\section{Conclusions}

A summary of the differences in the view of the state is provided in the table below.

\begin{tabular}{|l|l|l|}
\hline Property & Before Lokvani & After Lokvani \\
\hline Scarcity & $\begin{array}{l}\text { Three ways of accessing the state, } \\
\text { though each was scarce for marginal cit- } \\
\text { izens } \\
\text { Exit was a way of life }\end{array}$ & $\begin{array}{l}\text { Scarcity is reduced, particularly for ac- } \\
\text { efited the DM; marginal citizens ben- } \\
\text { Lokvani is a means to exit earlier en- } \\
\text { gagements and re-enter new ones } \\
\text { Voice is heard and localised; the state } \\
\text { remains the same } \\
\text { Same as before }\end{array}$ \\
Violence & Voice was limited & Police aligned with dominant groups \\
\hline
\end{tabular}

This paper addresses a gap in the e-government literature, that of an adequate theory of the state. The analysis of the data shows that when e-government systems are implemented the view of the state, for the target population of the e-government project, changes. When seen from the theoretical lens of scarcity, exit, voice and violence of the state, we find that the e-government system changes some of the these properties.

These findings have two implications for e-government research and practice. 1) The legitimacy of the sovereign state is bound in the will of the people [3], so the view the people have of the state is very important. As Lokvani is a new 'face' of the government (not the only one though), its evaluation also has to include its new view. Evaluations of all e-government systems thus should include how citizens view the state, and how their perceptions change, not just of the system alone. 2) An explicit understanding of the view that citizens have of the state will enhance practice of e-government design and deployment. Citizens experience the state through the technologies that it deploys. When systems are deployed that enable and amplify access and voice, they should also ensure that marginal citizens do not have to exit their engagement as their concerns are not redressed. Further, design of the systems could address the issue of violence, by seeking possible mechanisms that preclude it. 


\section{References}

1. Andersen, K., Henriksen, H.: E-government maturity models: Extension of the Layne and Lee model. Government Information Quarterly 23, 236-248 (2006)

2. Avegerou, C., McGrath, K.: Power, rationality, and the art of living through sociotechnical change. MIS Quarterly 31(2), 296-315 (2007)

3. Chatterjee, P.: The Politics of the Governed: Reflections on Popular Politics in Most of the World. Columbia University Press, Englewood Cliffs (2004)

4. Corbridge, S., Williams, G., Srivastava, M., Veron, R.: Seeing the State: Governance and Governmentality in India. Cambridge University Press, Cambridge (2005)

5. De', R.: Control, de-politicization and the eState. In: Wimmer, M.A., Scholl, H.J., Ferro, E. (eds.) EGOV 2008. LNCS, vol. 5184, pp. 61-72. Springer, Heidelberg (2008)

6. De', R.: Caste structures and e-governance in a developing country. In: Wimmer, M.A., Scholl, H.J., Janssen, M., Traunmüller, R. (eds.) EGOV 2009. LNCS, vol. 5693, pp. 40-53. Springer, Heidelberg (2009)

7. Heeks, R., Bailur, S.: Analyzing e-government research: Perspectives, philosophies, theories, methods, and practice. Government Information Quarterly 24, 243-265 (2007)

8. Hirschman, A.O.: Exit, Voice, and Loyalty: Responses to Decline in Firms, Organizations, and States. Harvard University Press, Cambridge (1970)

9. Hirschman, A.O.: Exit, voice, and the state. World Politics 31(1), 90-107 (1978)

10. Layne, K., Lee, J.: Developing fully functional e-government: A four stage model. Government Information Quarterly 18, 122-136 (2001)

11. Pai, S.: Social capital, panchayats and grass roots democracy: Politics of dalit assertion in Uttar Pradesh. Economic and Political Weekly 36(8), 645-654 (2001)

12. Sassen, S.: Territory Authority Rights: From Medieval to Global Assemblages. Princeton University Press, Princeton (2006)

13. Sharma, A., Gupta, A.: The Anthropology of the State: A Reader. In: chap. Introduction, pp. 1-42. Blackwell, Malden (2006)

14. Shukla, A., Srinivasan, R.: Lokvani: A case of public private partnership in egovernance. In: Communication Proceedings of the Fifth International eGOV Conference. Trauner Verlag (2006)

15. Silva, L., Hirschheim, R.: Fighting against windmills: Strategic information systems and organizational deep structures. MIS Quarterly 31(2), 327-354 (2007)

16. Venugopal, V., Yilmaz, S.: Decentralization in Kerala: Panchayat government discretion and accountability. Public Administration and Development 29(4), 316-329 (2009)

17. Yildiz, M.: E-government research: Reviewing the literature, limitations, and ways forward. Government Information Quarterly 24, 646-665 (2007)

18. Yin, R.K.: Case Study Research: Design and Methods, Applied Social Science Research Methods Series, vol. 5. Sage Publications, Thousand Oaks (2003) 